\title{
Trimethylaminuria (Case study)
}

\author{
Trimetilaminúria (Estudo de caso)
}

Bruno Sousa $^{(1,2,3)}$, Rui Silva ${ }^{(3)}$, Nelson Tavares ${ }^{(1,2)}$

${ }^{1}$ School of Sciences and Health Technologies, Universidade Lusófona de Humanidades e Tecnologias, Lisboa, Portugal

${ }^{2} \mathrm{CBIOS}$ - Research Center for Biosciences and Health Technologies

${ }^{3}$ Health Service of Autonomous Region of Madeira

Email: nelson.tavares@ulusofona.pt

Received /Recebido: 03/04/2019 Accepted / Aceite: 04/04/2019

Electronic Edition: www.alies.pt

A 39-year-old female civil servant was sent to the Nutrition consultation for food and nutrition monitoring after she went to her attending physician with complaints of intense and unpleasant body odor, as well as foulsmelling urine. According to the patient, the situation would have been due to eating some squid that were spoiled. The hypotheses of urinary infection, vaginal Trichomoniasis and Trimethylaminuria were placed by the physician.

Anthropometric evaluation

Weight: $82.5 \mathrm{~kg}$

Height: $158 \mathrm{~cm}$

BMI: $33.0 \mathrm{~kg} / \mathrm{m}^{2}$

Waist circumference: $97 \mathrm{~cm}$

Body composition evaluation (TANITA TBF $300^{\circledR}$ )

Body fat: $38.9 \%$

Fat mass: $32.1 \mathrm{~kg}$

Fat free mass: $50.4 \mathrm{~kg}$

Total body water: $36.9 \mathrm{~kg}$

Analytical Parameters:

Hematology

Leukocytes: $6.2 \times 10^{3} / \mu \mathrm{L}(4.5-11.0)$

Erythrocytes: $4.32 \times 10^{6} / \mu \mathrm{L}(3.80-5.80)$

Hemoglobin: $12.5 \mathrm{~g} / \mathrm{dL}(11.5-16.0)$

Hematocrit: $37.8 \%$ (37.0 - 47.0)

Sedimentation rate: $39 \mathrm{~mm}(<30)$

Biochemistry

Glucose: $96 \mathrm{mg} / \mathrm{dL}(74.0-110.0)$

Urea: $31.2 \mathrm{mg} / \mathrm{dL}(8.0-50.0)$

Creatinine: $0.97 \mathrm{mg} / \mathrm{dL}(0.70-1.20)$

Alanine Aminotransferase: 14.0 U/L (14.0-54.0)
Uma mulher de 39 anos, funcionária pública, foi encaminhada à consulta de Nutrição para acompanhamento de alimentação e nutrição, após ter procurado o seu médico assistente com queixas de odor corporal intenso e desagradável, além de urina fétida. Segundo a própria, a situação ter-se-ia ficado a dever a umas potas de comeu e que estariam estragadas. As hipóteses de infecção urinária, tricomoníase vaginal e trimetilaminúria foram colocadas pelo médico.

Avaliação antropométrica

Peso: $82,5 \mathrm{~kg}$

Estatura: $158 \mathrm{~cm}$

IMC: $33,0 \mathrm{~kg} / \mathrm{m}^{2}$

Perímetro da cintura: $97 \mathrm{~cm}$

Avaliação da composição corporal (TANITA TBF $300 \AA)$

Gordura corporal: $38,9 \%$

Massa gorda: $32,1 \mathrm{~kg}$

Massa isenta de gordura: $50,4 \mathrm{~kg}$

Água corporal total: $36,9 \mathrm{~kg}$

Parâmetros analíticos:

Hematologia

Leucócitos: $6,210^{\wedge} 3 / \mu \mathrm{L}(4,5-11,0)$

Eritrócitos: 4,32 10^6/ $\mu \mathrm{L}(3,80-5,80)$

Hemoglobina: $12,5 \mathrm{~g} / \mathrm{dL}(11,5-16,0)$

Hematócrito: $37,8 \%(37,0-47,0)$

Velocidade de sedimentação: $39 \mathrm{~mm}(<30)$

Bioquímica

Glicose: $96 \mathrm{mg} / \mathrm{dL}(74,0-110,0)$

Ureia: $31,2 \mathrm{mg} / \mathrm{dL}(8,0-50,0)$

Creatinina: $0,97 \mathrm{mg} / \mathrm{dL}(0,70-1,20)$ 
Aspartate Aminotransferase: 17.2 U/L (10.0-35.0)

C-reactive protein: $2.16 \mathrm{mg} / \mathrm{L}(<6.10)$

Urine type II: no change

Uroculture: negative

Clinical evaluation:

Personal background:

Obesity I

Iron deficiency anemia in 2016

Medication:

Levothyroxine sodium (1 tablet in the morning)

Complementary diagnostic tests

Genetic study (FMO3 gene sequencing study):

The study revealed the presence of variant p.Glu158Lys in homozygosity and variants c. $627+10 \mathrm{c}>\mathrm{G}$ and p.Glu308Gly both in heterozygosity in the FMO3 gene. These findings allow us to conclude that the patient presents the variants p.Glu158Lys and c. $627+10 \mathrm{C}>\mathrm{G}$, in cis (i.e., in the same allele). The presence of these variants in cis, is described in the literature as associated with a decrease in the activity of the enzyme Flavina mono-oxygenase 3 and consequently the manifestation of the typical phenotype of Trimethylaminuria.

Intestinal transit: regular

Eating habits:

Wake up: 6:30 AM

Breakfast: 7:45 AM

1 banana or apple

Morning snack: 10:00 AM

1 rye bread +1 cup semi-fat milk with coffee without sugar

Lunch: 12:30 PM

Dish: 2 to 3 tablespoons of white rice + meat or fish $(100 \mathrm{~g})+$ varied vegetables $(150 \mathrm{~g})$ seasoned with olive oil

Afternoon snack: 3:00 PM

3 Maria cookies +1 piece of fruit

Afternoon snack: 6:00 PM

1 white bread with 1 slice of cheese +1 cup of coffee with half-fat milk without sugar
Alanina Aminotransferase: 14,0U/L $(14,0-54,0)$

Aspartato Aminotransferase: 17,2U/L $(10,0-35,0)$

Proteína C reativa: $2,16 \mathrm{mg} / \mathrm{L}(<6,10)$

Urina tipo II: sem alterações

Urocultura: negativa

Avaliação clínica:

Antecedentes pessoais:

Obesidade I

Anemia ferropénica em 2016

Medicação:

Levotiroxina sódica (1 comprimido de manhã)

Exames complementares de diagnóstico

Estudo genético (sequenciação do gene FMO3):

O estudo revelou a presença da variante p.Glu158Lys em homozigotia e das variantes c. $627+10 c>G$ e p.Glu308Gly ambas em heterozigotia, no gene FMO3. Estes resultados permitem concluir que a paciente apresenta as variantes p.Glu158Lys e c. $627+10 \mathrm{C}>\mathrm{G}$, em cis (isto é, no mesmo alelo). A presença destas variantes em cis, está descrita na literatura como associada a uma diminuição da atividade da enzima Flavina mono-oxigenase 3 e consequentemente à manifestação do fenótipo típico de Trimetilaminúria.

Trânsito intestinal: regular

Hábitos alimentares:

Acorda às $6 \mathrm{~h} 30$

Pequeno-almoço: 7h45

1 banana ou maçã

Lanche da manhã: $10 \mathrm{~h}$

1 pão de centeio +1 chávena de leite meio gordo com café sem açúcar

Almoço: $12 \mathrm{~h} 30$

Prato: 2 a 3 colheres de sopa de arroz branco + carne ou peixe $(100 \mathrm{~g})+$ verdura variada $(150 \mathrm{~g})$ temperada com azeite

Lanche da tarde: $15 \mathrm{~h}$

3 bolachas Maria +1 peça de fruta 
Dinner: 10:00 PM

Dish: 3 potatoes or 4 tablespoons of white rice + meat or fish $(100 \mathrm{~g})+$ varied vegetables $(150 \mathrm{~g})$ seasoned with olive oil

Bed: 10:30 PM

Water / tea consumption: about 1.5 liters of water per day

Environment, behavior and social:

She lives with her husband and her 17-month-old son. She conciliates the life of home, with work activity and with high-level studies, which makes her availability for social activities scarce. She presents a sedentary activity lifestyle.

\section{Questions:}

1. How was the diagnosis made?

2. Which tests are most suitable for confirming the disease?

3. In addition to the confirmation of the diagnosis of Triamethylaminuria, what allows the verification of the genetic sequencing of the FMO3 gene?

4. Can symptoms improve or disappear throughout life?

5. What is the treatment?

6. What is the impact of the controlled diet on the patient's quality of life?

7. What is the prognosis and repercussions on the patient's health?

\section{Answers:}

1. Although the description of the odor did not refer to fish, the intensity described and the occurrence after the ingestion of a mollusk raised the suspicion reinforced by the patient having adequate hygiene habits and having no complaints of vaginal discharge or burning when urinating.

2. Once the differential diagnoses of vulvo-vaginitis, urinary tract infection, and cutaneous infection were eliminated, a genetic test was proposed to detect FMO3 gene alteration, associated with a decrease in the activity of the enzyme Flavin mono-oxygenase 3, which
Lanche da tarde: $18 \mathrm{~h}$

1 pão branco com 1 fatia de queijo +1 chávena de café com leite meio gordo sem açúcar

Jantar: $22 \mathrm{~h}$

Prato: 3 batatas ou 4 colheres de sopa de arroz branco + carne ou peixe $(100 \mathrm{~g})$ + verdura variada $(150 \mathrm{~g})$ temperada com azeite

Deita-se às $22 \mathrm{~h} 30$

Consumo de água/chá: cerca de 1,5 litros de água por dia

Ambiente, comportamento e social:

Vive com o marido e com filho de 17 meses. Concilia a vida de casa, com a atividade laboral e com os estudos de nível superior, o que faz com que a disponibilidade para atividades sociais sejam escassas. Apresenta uma atividade sedentária.

\section{Questões:}

Como foi determinado o diagnóstico?

Quais os exames mais adequados para a confirmação da doença?

Para além da confirmação do diagnóstico de Triametilaminúria o que permite verificar a sequenciação genética do gene FMO3?

Os sintomas podem melhorar ou desaparecer ao longo da vida?

Qual o tratamento?

Qual o impacto da dieta controlada na qualidade de vida do paciente?

Qual o prognóstico e repercussão na saúde do paciente?

\section{Respostas:}

1. Muito embora a descrição do odor não fizesse referência a peixe, a intensidade descrita e o facto de acontecer após a ingestão de um molusco, levantou a suspeita reforçada por a doente ter hábitos de higiene adequados e não ter queixas de corrimento vaginal ou ardor ao urinar.

2. Feito o diagnóstico diferencial de vulvo-vaginite, infecção urinária e infecção cutânea, foi proposta a realização do teste genético para despiste de alteração do gene FMO3, associado a uma diminuição da atividade da enzima Flavina mono-oxigenase 3 que metaboliza, 
metabolizes trimethylamine, which has an intense odor characteristic of fish, in the liver into odorless trimethylamine oxide. In other countries, there are also provocation tests by oral overload of trimethylamine, however, in Portugal only the genetic test, which confirms the disease, is available.

3. The results obtained also allow us to verify that the patient presents variants p.Glu158Lys and p.Glu308Gly also in cis, which is described in the literature as associated to the manifestation of the moderate phenotype of Trimethylaminuria. Thus, the results obtained are compatible with the diagnosis of Trimethylaminuria, also known as Fish Smell Syndrome, of autosomal recessive transmission (OMIM \# 602979).

4. The disease has fluctuations that are fundamentally related to diet. In literature, improvement during pregnancy by unclarified, eventually hormonal mechanisms is described (1).

5. There is no treatment. In a study carried out in Portugal (2) in 52 patients with a TMAu suggestive phenotype, the presence of pathogenic polymorphisms and / or mutations in the FMO3 gene was confirmed, and 32 variants were found to condition different degrees of severity. The approach is food counseling as defined by a nutritionist. The balanced management of body hygiene and clothing complete these measures.

6. The earlier the disease is diagnosed, the better the quality of life with only a controlled diet, low in choline and triethylamines, namely avoiding the ingestion of eggs, soybeans, legumes, genus Brassica sp. (3). The affected individual will have a normal life, ceasing to be stigmatized for lack of bodily hygiene and not suffering the consequences of social exclusion.

7. The prognosis is good and does not constitute a direct danger to life, although in many cases the psychological aspects may have important consequences (4). The repercussions on mental health, fear of social interaction, and, possibly, self-image issues can be devastating (4). no fígado, a trimetilamina, com cheiro intenso característico do peixe, em óxido de trimetilamina, inodoro. Emboram existam, noutros países, teste de provocação com sobrecarga oral de trimetilamina, em Portugal só está disponível o teste genético, que confirma a doença.

3. Os resultados obtidos permitem ainda verificar que a paciente apresenta as variantes p.Glu158Lys e p.Glu308Gly também em cis, o que está descrito na literatura como associado à manifestação do fenótipo moderado de Trimetilaminúria. Assim, os resultados obtidos são compatíveis com o diagnóstico de Trimetilaminúria, também conhecido como Síndrome de odor a peixe, de transmissão autossómica recessiva (OMIM\#602979).

4. A doença tem flutuações que decorrem, fundamentalmente, da dieta. Está descrita, na literatura, a melhoria durante a gravidez por mecanismos não esclarecidos, eventualmente hormonais (1).

5. Não existe tratamento. Num estudo realizado em Portugal (2) em 52 doentes estudados com fenótipo sugestivo de TMAu foi confirmada a presença de polimorfismos e/ou mutações patogénicas no gene FMO3, tendo-se observado 32 variantes que condicionam diferentes graus de severidade. A abordagem consiste num aconselhamento alimentar definido por um nutricionista. A gestão equilibrada da higiene corporal e da roupa, completam estas medidas.

6. Quanto mais precoce esta doença for diagnosticada melhor será a qualidade de vida do indivíduo afectado que com apenas uma dieta controlada (com baixo teor em colina e trietilaminas, nomeadamente, evitar a ingestão de ovos, soja, leguminosas, frutos secos e legumes do género Brassica sp.) terá uma vida normal, deixando de ser estigmatizado por falta de higiene corporal não sofrendo as consequências da exclusão social (3).

7. O prognóstico é bom, não constituindo perigo directos para a vida, embora os aspectos psicológicos possam ter, em muitos casos, consequências importantes (4). A repercussão na saúde mental, pelo receio do convívio social e, eventualmente, por questões de auto-imagem, podem ser devastadora (4). 


\section{References/Referências:}

1. Hukkanen J, Dempsey D, Jacob P 3rd, Benowitz NL. Effect of pregnancy on a measure of FMO3 activity. Br J Clin Pharmacol. 2005 Aug;60(2):224-6.

2. Vilarinho L, Ferreira F, Almeida L, et al. Contribuição dos polimorfismos no gene FMO3 na patologia e na farmacogenética. Acta Farmacêutica Portuguesa 2015, vol. 4, n. 1, pp. 34-41.

3. Ferreira F, Almeida L, Gaspar A et al. Trimetilaminúria (Síndroma de odor a peixe) uma doença subestimada: espectro mutacional da população portuguesa. Boletim Epidemiológico Observações, 2015; 4:37-39.

4. Messenger J1, Clark S, Massick S, Bechtel M. A review of trimethylaminuria: (fish odor syndrome). J Clin Aesthet Dermatol. 2013 Nov;6(11):45-8. 